\title{
Effect of silver nanoparticles on human mesenchymal stem cell differentiation
}

\author{
Christina Sengstock $^{* 1}$, Jörg Diendorf ${ }^{2}$, Matthias Epple ${ }^{2}$, Thomas A. Schildhauer ${ }^{1}$ \\ and Manfred Köller ${ }^{1}$
}

\section{Full Research Paper}

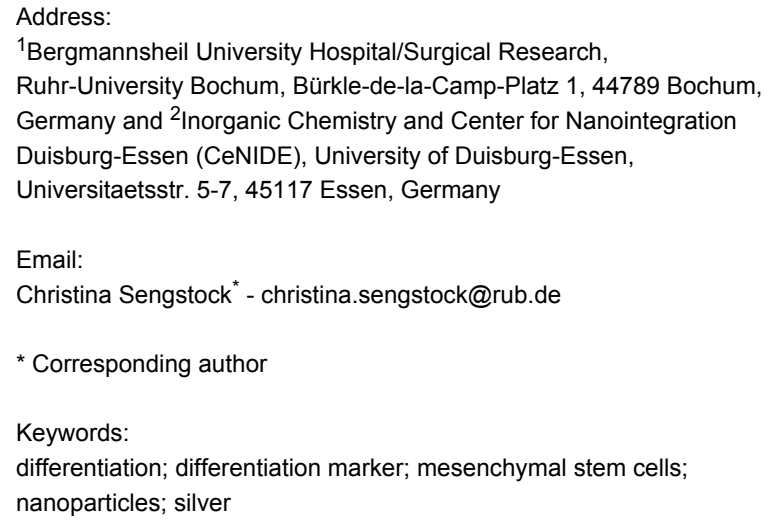

Beilstein J. Nanotechnol. 2014, 5, 2058-2069. doi:10.3762/bjnano.5.214

Received: 10 February 2014

Accepted: 22 October 2014

Published: 10 November 2014

This article is part of the Thematic Series "Biological responses to NPs".

Guest Editor: R. Zellner

(C) 2014 Sengstock et al; licensee Beilstein-Institut. License and terms: see end of document.

\begin{abstract}
Background: Silver nanoparticles (Ag-NP) are one of the fastest growing products in nano-medicine due to their enhanced antibacterial activity at the nanoscale level. In biomedicine, hundreds of products have been coated with Ag-NP. For example, various medical devices include silver, such as surgical instruments, bone implants and wound dressings. After the degradation of these materials, or depending on the coating technique, silver in nanoparticle or ion form can be released and may come into close contact with tissues and cells. Despite incorporation of Ag-NP as an antibacterial agent in different products, the toxicological and biological effects of silver in the human body after long-term and low-concentration exposure are not well understood. In the current study, we investigated the effects of both ionic and nanoparticulate silver on the differentiation of human mesenchymal stem cells (hMSCs) into adipogenic, osteogenic and chondrogenic lineages and on the secretion of the respective differentiation markers adiponectin, osteocalcin and aggrecan.
\end{abstract}

Results: As shown through laser scanning microscopy, Ag-NP with a size of $80 \mathrm{~nm}$ (hydrodynamic diameter) were taken up into hMSCs as nanoparticulate material. After $24 \mathrm{~h}$ of incubation, these Ag-NP were mainly found in the endo-lysosomal cell compartment as agglomerated material. Cytotoxicity was observed for differentiated or undifferentiated hMSCs treated with high silver concentrations ( $\geq 20 \mu \mathrm{g} \cdot \mathrm{mL}^{-1} \mathrm{Ag}-\mathrm{NP} ; \geq 1.5 \mu \mathrm{g} \cdot \mathrm{mL}^{-1} \mathrm{Ag}^{+}$ions) but not with low-concentration treatments $\left(\leq 10 \mu \mathrm{g} \cdot \mathrm{mL}^{-1} \mathrm{Ag}-\mathrm{NP}\right.$; $\leq 1.0 \mu \mathrm{g} \cdot \mathrm{mL}^{-1} \mathrm{Ag}^{+}$ions). Subtoxic concentrations of $\mathrm{Ag}-\mathrm{NP}$ and $\mathrm{Ag}^{+}$ions impaired the adipogenic and osteogenic differentiation of hMSCs in a concentration-dependent manner, whereas chondrogenic differentiation was unaffected after $21 \mathrm{~d}$ of incubation. In contrast to aggrecan, the inhibitory effect of adipogenic and osteogenic differentiation was confirmed by a decrease in the secretion of specific biomarkers, including adiponectin (adipocytes) and osteocalcin (osteoblasts). 
Conclusion: Aside from the well-studied antibacterial effect of silver, little is known about the influence of nano-silver on cell differentiation processes. Our results demonstrate that ionic or nanoparticulate silver attenuates the adipogenic and osteogenic differentiation of hMSCs even at non-toxic concentrations. Therefore, more studies are needed to investigate the effects of silver species on cells at low concentrations during long-term treatment.

\section{Introduction}

Novel nanomaterials are being developed to enhance the diagnoses and treatment of diseases through the improved delivery of drugs, biopharmaceutical molecules and imaging agents to target cells at the sites of disease as well as through the surface treatment of biomaterials, such as implants. Ag-NP have a high degree of commercialization among current nanomaterials mainly due to their well-known antiseptic activities [1] Presently, there are over 600 commercialized products on the market made from engineered nanomaterials, and Ag-NP are contained in approximately 250 of these products [2,3]. In the medical sector, various Ag nanomaterials have been used in numerous devices and products, such as silver sulfadiazine in the treatment of burns to reduce skin infections. Furthermore, silver has been used to coat a variety of different surfaces, such as catheters [4-7], or it has been incorporated into a hydrogel network for wound healing [8]. In our previous studies on the biological effects of Ag-NP (PVP-coated, $80 \mathrm{~nm}$ ) on human mesenchymal stem cells (hMSCs), we have shown that cell activation could occur at elevated but non-toxic silver concentrations $[9,10]$. In addition, we have shown that hMSCs are able to ingest Ag-NP through clathrin-dependent endocytosis and by macropinocytosis and that silver agglomerates were formed in the cytoplasm following the uptake of these nanoparticles [11]. There is a general consensus that dissolved silver ions are responsible for the majority of the biological effects on various cells and that the generation of reactive oxygen species is involved in the silver-induced cell response [9,12-16].

Previously, we have shown that silver ions are more toxic to hMSCs than Ag-NP (in terms of the absolute concentration of silver) $[9,10]$. This effect is approximately three times higher for silver ions than for Ag-NP; however, the biological effects induced by both nanoparticulate and ionic silver occurred in the same respective concentration ranges for eukaryotic cells and microorganisms [17-19]. We and others have studied the mechanisms underlying silver ion release from nanoparticles [20,21] The release of silver ions seems to involve a cooperative oxidation process that requires both dissolved dioxygen and protons. The ion release rates increase with temperature in the range of $0-37{ }^{\circ} \mathrm{C}$ and decrease with increasing $\mathrm{pH}[21,22]$. However, the presence of ligands (such as $\mathrm{SO}_{4}{ }^{2-}, \mathrm{S}^{2-}$ ) in the microenvironment considerably decreased the adverse effects of silver ions and silver nanoparticles, indicating that these ligands bind silver $[18,23]$. Today, Ag-NP are increasingly used because particles with sizes in the range of a few nanometers lead to a dramatic increase in the surface area/mass ratio in contrast to micrometer-sized particles. Such an enlargement of the reactive surface area will lead to the effective release of silver ions $\left(\mathrm{Ag}^{+}\right)$in parallel with low total silver concentrations, resulting in an increased release effect with respect to the applied mass of silver [23,24].

Because of the high differentiating capacity of hMSCs they are an optimal cell model to analyze the possible influence of silver nanoparticles on cell differentiation. MSCs are neither transformed nor immortalized cells, rather, they represent primary pre-tissue cells. They can therefore be cultured for weeks without cell passage, which is important for long-term studies [25]. Furthermore, MSCs contribute to the regeneration and repair of mesenchymal tissues such as bone, cartilage, muscle, ligaments, tendons, adipose tissue and stroma [26].

Ag-NP and $\mathrm{Ag}^{+}$ions have been reported to bind rapidly to biomolecules, such as DNA [27], negatively charged cell-wall components and the sulfhydryl groups of metabolic enzymes $[7,28,29]$, which results in the inhibition of DNA-replication, an increase in membrane permeability and the disturbance of different metabolic pathways [30]. In contrast to the vast number of toxicological and microbiological studies [7,9,21], only a few studies have investigated whether the differentiation potential of hMSCs was maintained after the uptake of different nanoparticles [31-33].

Therefore, the aim of this study was to investigate the cellular uptake of nano-silver by hMSCs and the influence of nanoparticulate or ionic silver on the viability and differentiation potential of these cells. The viability and adipogenic, osteogenic and chondrogenic differentiation potential were examined qualitatively and quantitatively through light and fluorescence microscopy, photometry and by analyzing the secretion of typical biomarkers.

\section{Results \\ Uptake and intracellular distribution of nano- silver in hMSCs}

Human MSCs were cultured in the presence of $20 \mu \mathrm{g} \cdot \mathrm{mL}^{-1}$ Ag-NP at $37{ }^{\circ} \mathrm{C}$ for $24 \mathrm{~h}$ under cell culture conditions, and the cell nucleus and endo-lysosomes were labeled with specific 
organelle markers. Laser scanning microscopy and phasecontrast microscopy were performed in parallel on identical cell areas (Figure 1A). In cells cultured in the presence of Ag-NPs, agglomerated nanoparticles were visible in a region close to the cell nucleus but not in the cell culture medium outside the cells. As shown in Figure 1D, silver agglomerates were mainly found associated with the endo-lysosomal areas (white arrow denotes silver agglomerates) but not inside the nucleus (Figure 1A and Figure 1D). A similar culture of hMSCs, in the presence of silver acetate (data not shown), did not reveal any silver agglomerate formation.

\section{Adipogenic differentiation of hMSCs after silver exposure}

In order to analyze the influence of nano-silver on the viability of undifferentiated cells (as a negative control) and on adipogenic-differentiated stem cells, hMSCs were cultured in the presence of different concentrations of $\mathrm{Ag}-\mathrm{NP} / \mathrm{Ag}^{+}$ions for $24 \mathrm{~h}$. The medium that contained the particles was subsequently removed and exchanged with pure RPMI/FCS (for undifferentiated cells) or adipogenic-differentiation medium, and the hMSCs were further cultivated for $14 \mathrm{~d}$. As shown in Figure 2A, the silver concentrations used are not toxic to undifferentiated hMSCs after $14 \mathrm{~d}$ of incubation, which confirms our earlier reports $[9,10,17,19]$. Similarly, the addition of Ag-NP (black bars) or $\mathrm{Ag}^{+}$ions (grey bars) did not decrease the viability of adipogenic-differentiated hMSCs at the concentrations used (Figure 2B).

To confirm adipogenic differentiation, the lipid content of the cells was visualized by using oil red O or Bodipy $493 / 503$ staining. As shown in Figure 3C, hMSCs differentiated into adipocytes in the presence of adipogenic-differentiation media (positive control; Figure 3C), in contrast to cells that were cultivated in the presence of RPMI/FCS (negative control; Figure 3A). Differentiated hMSCs changed their morphology from a fibroblast-like form (Figure $3 \mathrm{~A}$ ) to a spherical one with intracellular lipid droplets (Figure 3C). Cells that were additionally treated with $10 \mu \mathrm{g} \cdot \mathrm{mL}^{-1} \mathrm{Ag}-\mathrm{NP}$ (Figure 3B) or $1.0 \mu \mathrm{g} \cdot \mathrm{mL}^{-1} \mathrm{Ag}^{+}$ions (Figure $3 \mathrm{D}$ ) revealed no significant morphological changes compared with cells cultured without silver (Figure 3C). However, a large decrease in the number of formed lipid droplets was observed in the presence of a high concentration of $\mathrm{Ag}-\mathrm{NP}$ or $\mathrm{Ag}^{+}$ions (Figure $3 \mathrm{~B}$ and Figure 3D).

The adipogenic differentiation of hMSCs was quantified by the optical density $(520 \mathrm{~nm})$ of the extracted oil red-stained lipid droplets and by phase analysis of cells stained with Bodipy ${ }^{493 / 503}$. As shown in Figure 4, the quantification of

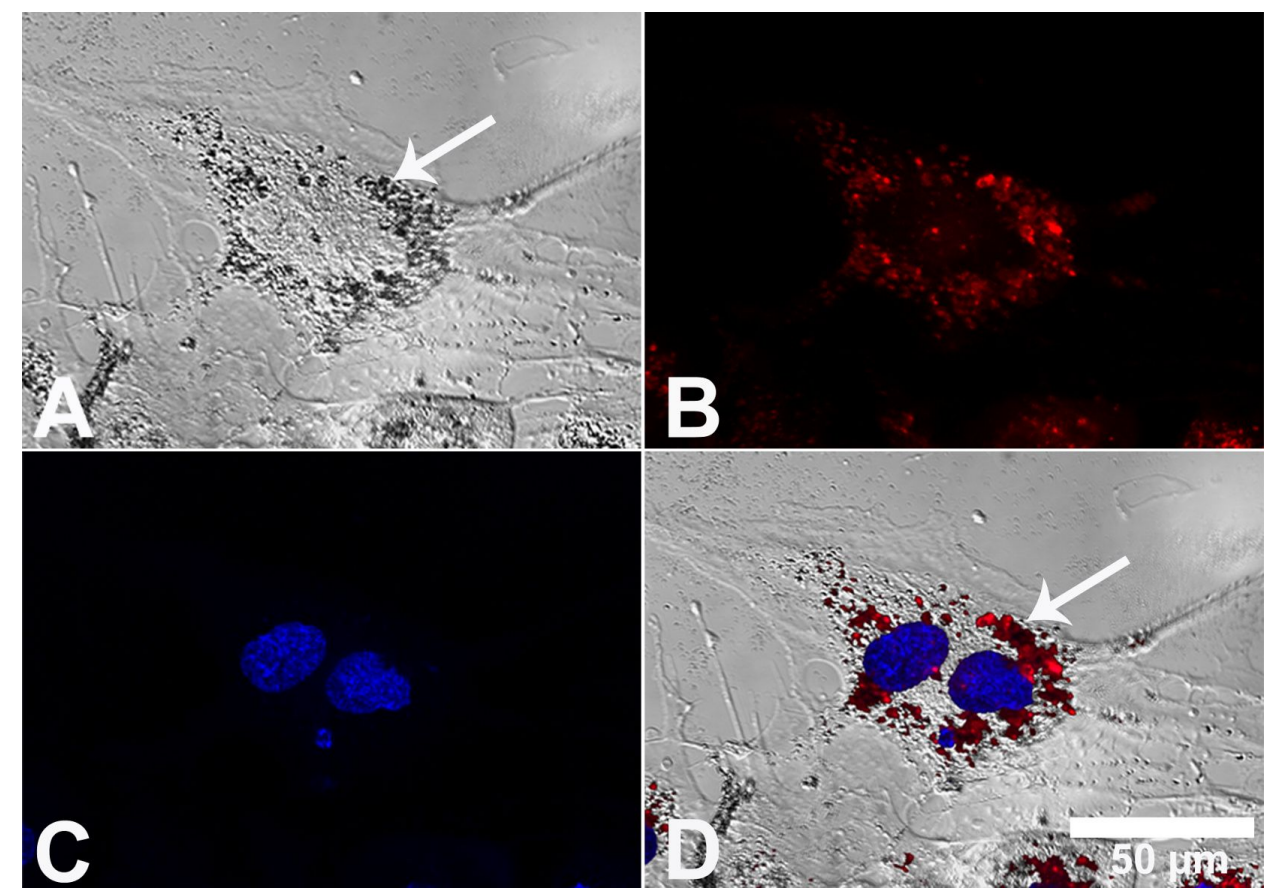

Figure 1: Localization of Ag-NP agglomerates in hMSCs. Representative light micrographs after digital contrast enhancement (DCE filter) (A), laser scanning micrographs $(B, C)$ and combinations of both $(D)$ are shown. The white arrow denotes the intracellular accumulation of silver particles inside the endo-lysosomes (A,D). The blue fluorescence of Hoechst 33342 and the red fluorescence of LysoTracker Red DND 99, which were used as probes of the cell nucleus (C) and endo-lysosomes (B), respectively, are shown. 

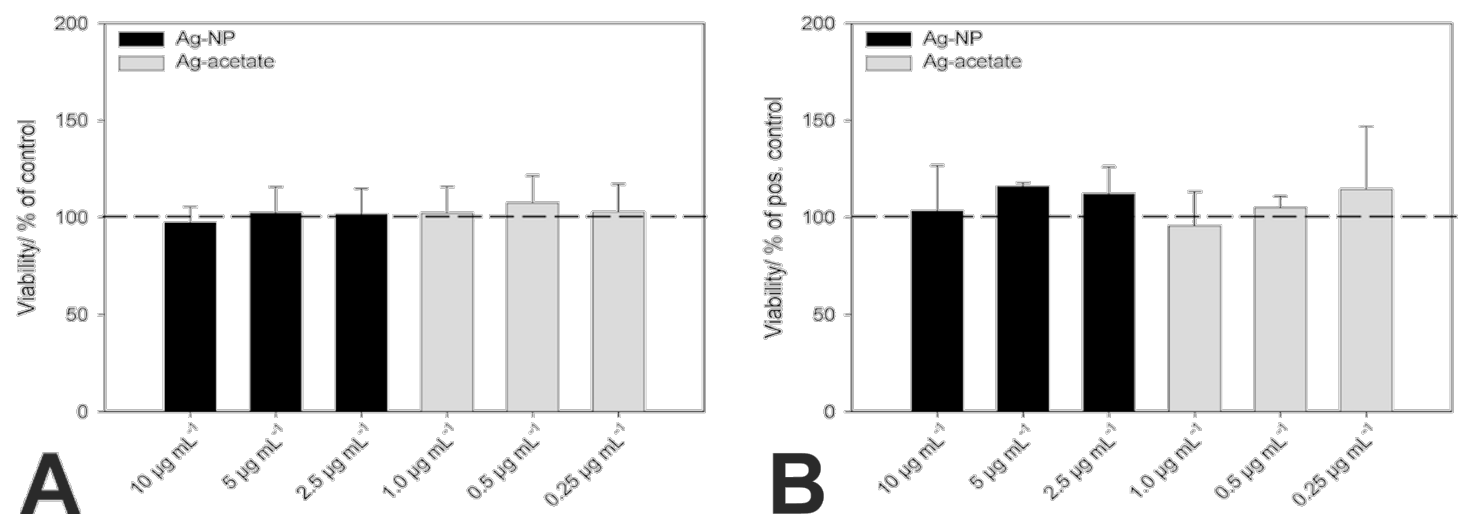

Figure 2: Influence of different $\mathrm{Ag}-\mathrm{NP} / \mathrm{Ag}^{+}$ion concentrations on the viability of undifferentiated hMSCs (A) and adipogenic-differentiated hMSCs (B). After $14 \mathrm{~d}$ of incubation, viable cells were stained with calcein-AM (green fluorescence) and quantified by using digital image processing (phase analysis). The data are expressed as the mean $\pm \operatorname{SD}(n=3$ independent experiments) given as the percentage of viable cells cultured in the presence of RPMI/FCS (A) or in the presence of adipogenic-differentiation medium (B).

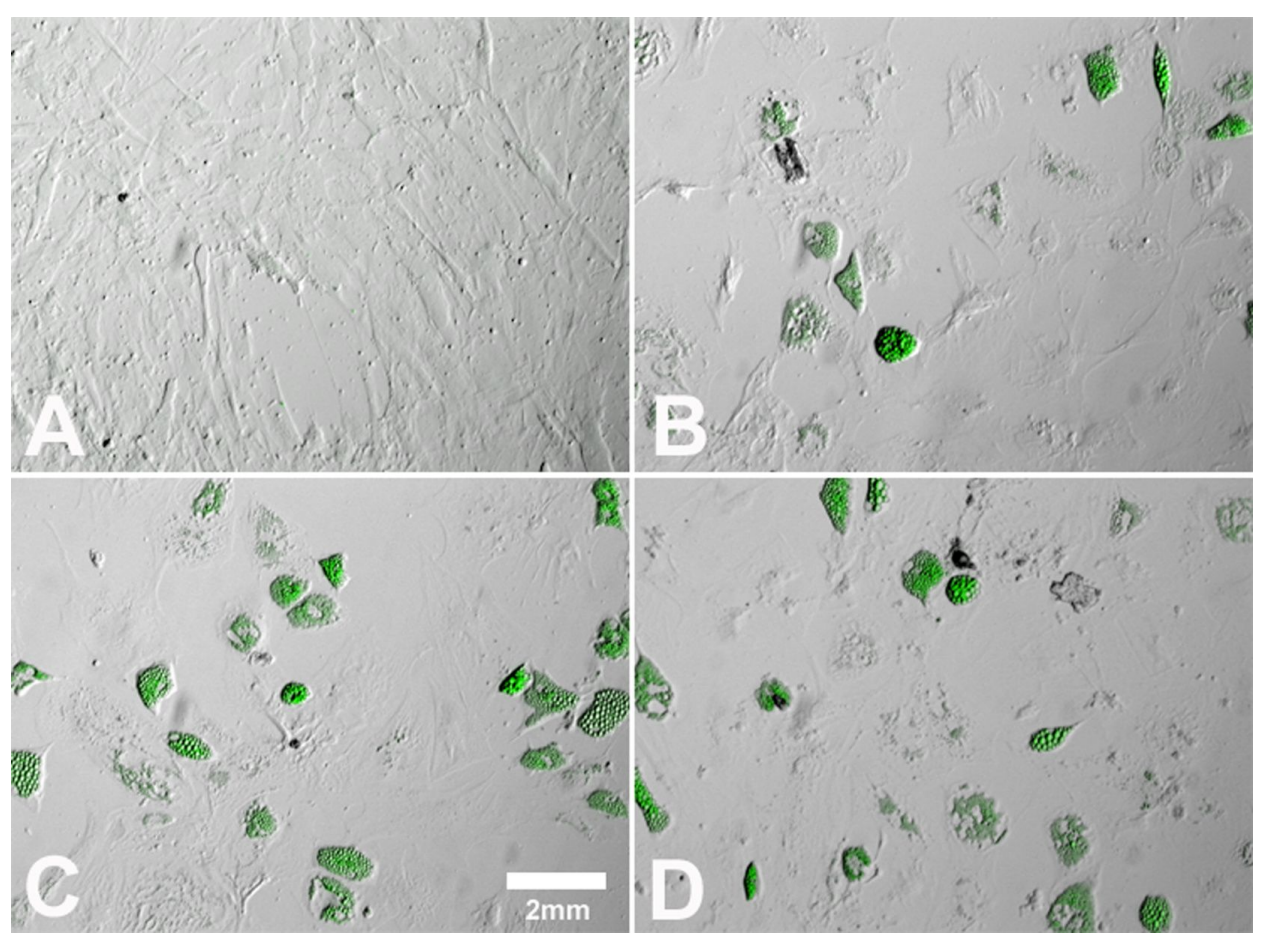

Figure 3: Influence of $\mathrm{Ag}-\mathrm{NP} / \mathrm{Ag}^{+}$ions on the adipogenic differentiation of hMSCs. After $14 \mathrm{~d}$ of cell culture (bright-field and fluorescence images), Bodipy ${ }^{493 / 503}$ staining was used to visualize lipid vacuoles in cells cultured under adipogenic conditions. hMSCs incubated in the presence of RPMl/ $10 \%$ FCS served as a negative control (A). hMSCs incubated in the presence of adipogenic-differentiation media served as a positive control (C). Cells were incubated with $10 \mu \mathrm{g} \cdot \mathrm{mL}^{-1} \mathrm{Ag}-\mathrm{NP}(\mathrm{B})$ or with $1.0 \mu \mathrm{g} \cdot \mathrm{mL}^{-1} \mathrm{Ag}^{+}$ions (D) for $24 \mathrm{~h}$ and were subsequently incubated with pure adipogenic-differentiation media for further $14 \mathrm{~d}$.

oil red (Figure 4A) and Bodipy $493 / 503$ (Figure 4B) revealed a decrease in lipid vacuoles with increasing silver concentrations. This decrease was significant at the applied concentrations of $10 \mu \mathrm{g} \cdot \mathrm{mL}^{-1}$ for Ag-NP (black bars) or $1.0 \mu \mathrm{g} \cdot \mathrm{mL}^{-1}$ for $\mathrm{Ag}^{+}$ ions (grey bars). The differences between oil red extraction and phase analysis after Bodipy ${ }^{493 / 503}$ staining may be due to the different extraction of oil red in the presence of silver.
To further investigate the effect of Ag-NP on the adipogenic differentiation of hMSCs, the expression of adiponectin was analyzed by using ELISA. Adiponectin is specifically secreted by adipose tissue and can be used as a marker for the adipogenic differentiation of MSCs. As shown in Figure 5, the release of adiponectin decreased significantly at Ag-NP concentrations of $5 \mu \mathrm{g} \cdot \mathrm{mL}^{-1}$ and $10 \mu \mathrm{g} \cdot \mathrm{mL}^{-1}$ (black bars), in contrast 

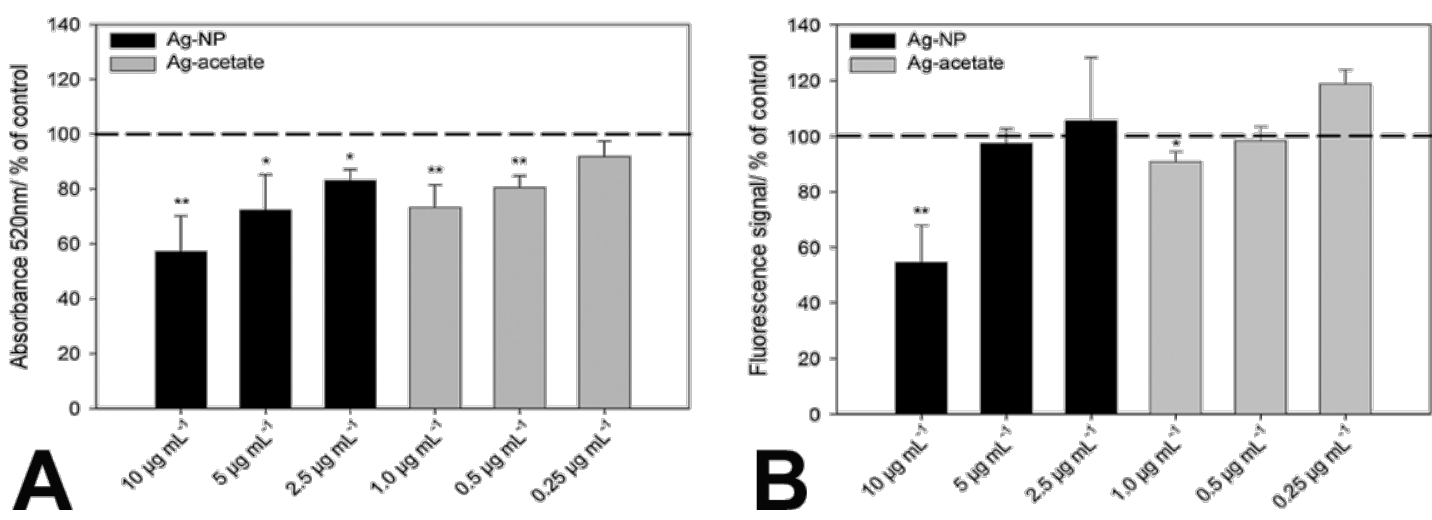

Figure 4: Influence of Ag-NP (black bars) or $\mathrm{Ag}^{+}$ions (grey bars) on the adipogenic differentiation of hMSCs after $14 \mathrm{~d}$ of incubation. Quantitative analyses of lipid droplet accumulation were performed by measuring the optical density $(520 \mathrm{~nm})$ of extracted oil red-stained lipid droplets (A) or by phase analysis of lipid droplets stained with Bodipy $493 / 503$ (B). The data are expressed as the mean \pm SD ( $n=3$ independent experiments) given as the percentage of cells cultured under adipogenic conditions in the absence of silver. The asterisks $\left(^{*}\right)$ indicate significant differences in comparison to the control $\left({ }^{*} p<0.05 ;{ }^{* *} p<0.005\right)$.

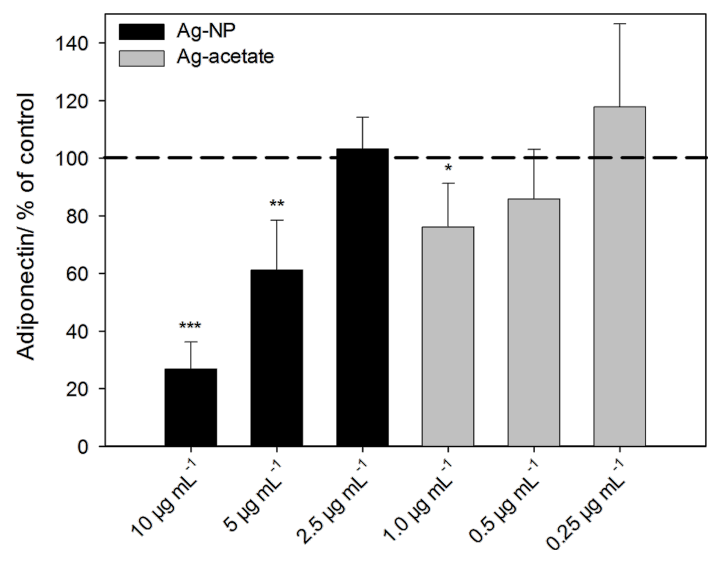

Figure 5: Release of the adipogenic differentiation marker adiponectin after hMSCs were incubated with $\mathrm{Ag}-\mathrm{NP} / \mathrm{Ag}^{+}$ions. After incubation with different concentrations of $\mathrm{Ag}-\mathrm{NP} / \mathrm{Ag}^{+}$ions for $24 \mathrm{~h}$, the silvertreated cells were washed, and particle-free medium (adipogenic-differentiation medium) was added. After $14 \mathrm{~d}$ of incubation, the amount of released adiponectin was measured. The data are expressed as the mean $\pm \mathrm{SD}$ ( $n=7$ independent experiments), given as the percentage of the control (Adiponectin $191 \pm 13 \mathrm{ng} \cdot \mathrm{mL}^{-1}$; cells cultured without silver, dashed line). The asterisks $\left(^{*}\right)$ indicate significant differences with respect to the control $\left({ }^{*} p<0.05,{ }^{* *} p<0.01,{ }^{* *} p<0.001\right)$.

to untreated control cells (dashed line). Similar results were observed in cells treated with $1 \mu \mathrm{g} \cdot \mathrm{mL}^{-1} \mathrm{Ag}^{+}$ions (grey bars).

\section{Osteogenic differentiation of hMSCs after silver exposure}

The viability of osteogenic-differentiated hMSCs was assessed as described in the Experimental section under quantitative cell differentiation. Undifferentiated cells were exposed to $\mathrm{Ag}-\mathrm{NP} / \mathrm{Ag}^{+}$ions for $24 \mathrm{~h}$ and then cultivated for $21 \mathrm{~d}$ in the presence of RPMI/FCS without extracellular silver. No signifi- cant decrease in viability was observed. Similar results were observed for hMSCs that were cultured in the presence of osteogenic-differentiation media after incubation with Ag-NP/Ag ${ }^{+}$ions (data not shown).

The influence of $\mathrm{Ag}-\mathrm{NP} / \mathrm{Ag}^{+}$ions on the osteogenic differentiation of hMSCs was investigated after a period of $21 \mathrm{~d}$. To confirm the differentiation of the $\mathrm{Ag}-\mathrm{NP} / \mathrm{Ag}^{+}$ion-treated hMSCs into osteoblasts, alizarin red S staining was carried out to verify the mineralization of the cells. hMSCs exposed to $10 \mu \mathrm{g} \cdot \mathrm{mL}^{-1}$ Ag-NP displayed no distinct morphological changes, but a decrease in the differentiation of hMSCs (Figure 6B) in contrast to cells cultured without silver (Figure 6C) was observed. In the presence of $\mathrm{Ag}^{+}$ions, no significant change in calcium accretion was measured (Figure 6D) in contrast to the positive control (Figure 6C).

The microscopic data were confirmed by quantitative analyses of osteogenic differentiation using cetylpyridinium chloride after the extraction of alizarin red. As shown in Figure 7, there was a significant change in calcium accretion after $21 \mathrm{~d}$ in the presence of $\mathrm{Ag}-\mathrm{NP}$. However, exposure to $\mathrm{Ag}^{+}$ions at any of the concentrations used did not influence the osteogenic differentiation potential under these conditions (Figure 7; grey bars).

Osteocalcin was measured by performing ELISA using the supernatants of cells that were differentiated into the osteogenic lineage. Osteocalcin is a suitable biomarker for osteogenic differentiation when differentiation is analyzed after a prolonged period of three weeks under differentiating conditions. Although alkaline phosphatase activity occurs earlier, osteocalcin expression is detectable in MSCs after the first week of osteogenic induction and remains detectable from then on [34]. 

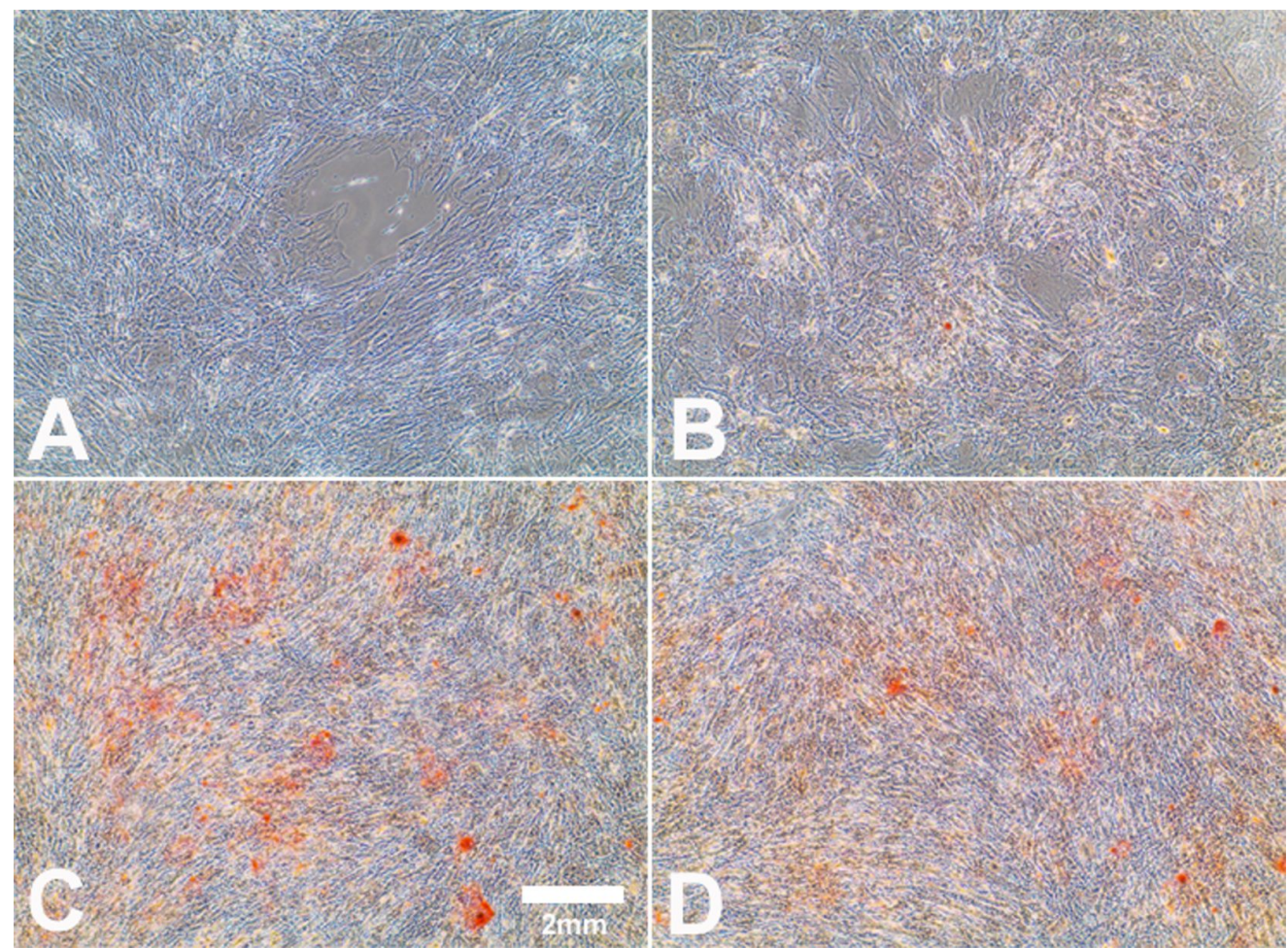

Figure 6: Influence of $\mathrm{Ag}-\mathrm{NP} / \mathrm{Ag}^{+}$ions on $\mathrm{hMSC}$ during osteogenic differentiation. After $21 \mathrm{~d}$ of cell culture (bright-field images), staining with alizarin red $\mathrm{S}$ was used to visualize calcium accretion in cells cultured under osteogenic conditions. hMSCs incubated in the presence of osteogenic-differentiation media served as the positive control (C). hMSCs incubated in the presence of RPMI/FCS served as the negative control (A). hMSCs incubated with $10 \mu \mathrm{g} \cdot \mathrm{mL}^{-1} \mathrm{Ag}-\mathrm{NP}(\mathrm{B})$ or with $1.0 \mu \mathrm{g} \cdot \mathrm{mL}^{-1} \mathrm{Ag}^{+}$ions (D) for $24 \mathrm{~h}$, and followed by osteogenic-differentiation media for a further $21 \mathrm{~d}$.

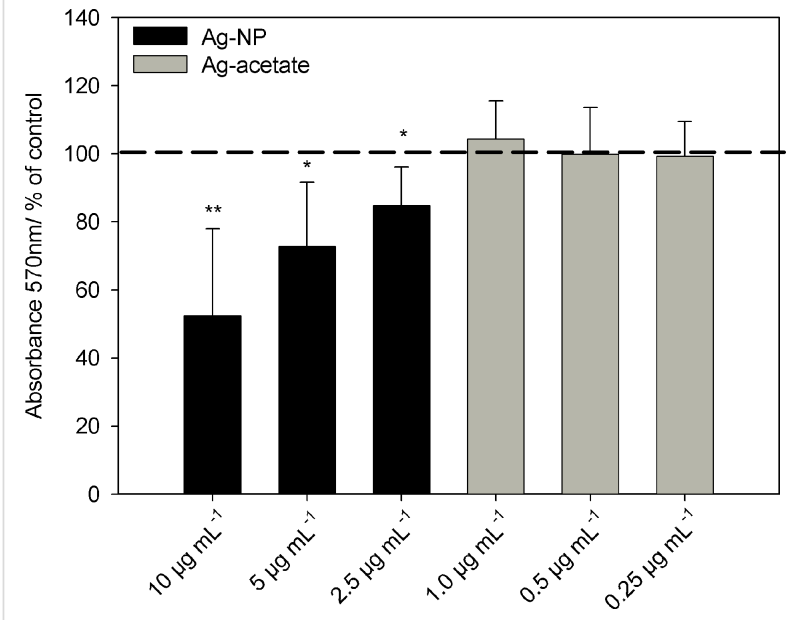

Figure 7: Influence of $\mathrm{Ag}-\mathrm{NP} / \mathrm{Ag}^{+}$ions on the osteogenic differentiation of hMSCs after $21 \mathrm{~d}$ of incubation. Quantitative analyses of mineralization were performed by measuring the optical density $(570 \mathrm{~nm})$ of extracted alizarin red S. The data are expressed as the mean $\pm \mathrm{SD}$ ( $n=3$ independent experiments), given as the percentage of cells cultured under osteogenic conditions in the absence of silver. The asterisks $\left(^{*}\right)$ indicate significant differences with respect to to the control $\left({ }^{*} p<0.05 ;{ }^{* *} p<0.005\right)$.
After $21 \mathrm{~d}$ of osteogenic differentiation the expression of osteocalcin was significantly decreased at $10 \mu \mathrm{g} \cdot \mathrm{mL}^{-1} \mathrm{Ag}-\mathrm{NP}$ or $1 \mu \mathrm{g} \cdot \mathrm{mL}^{-1} \mathrm{Ag}^{+}$ions (Figure 8).

\section{Chondrogenic differentiation of hMSCs after silver exposure}

The viability of chondrogenic-differentiated cells was analyzed by calcein-AM staining and revealed viable cells. However, a quantitative analysis was not possible due to the typical cell conversion as a pellet. Silver concentration-dependent differences in the conversion process or in the pellet size were not observed.

To investigate the effect of $\mathrm{Ag}-\mathrm{NP} / \mathrm{Ag}^{+}$ions on the chondrogenic differentiation of hMSCs, alcian blue staining was used to visualize chondrocyte-typical proteoglycans. As shown in Figure 9, the potential for hMSCs to differentiate into chondrocytes was not influenced by the treatment with Ag-NP or $\mathrm{Ag}^{+}$ ions. No qualitative differences with respect to the intensity and distribution of alcian blue staining were found between cells that were cultured with or without silver. The size of the pellets (longest diameter) ranged from $200-900 \mu \mathrm{m}$ regardless of the presence or absence of silver. 


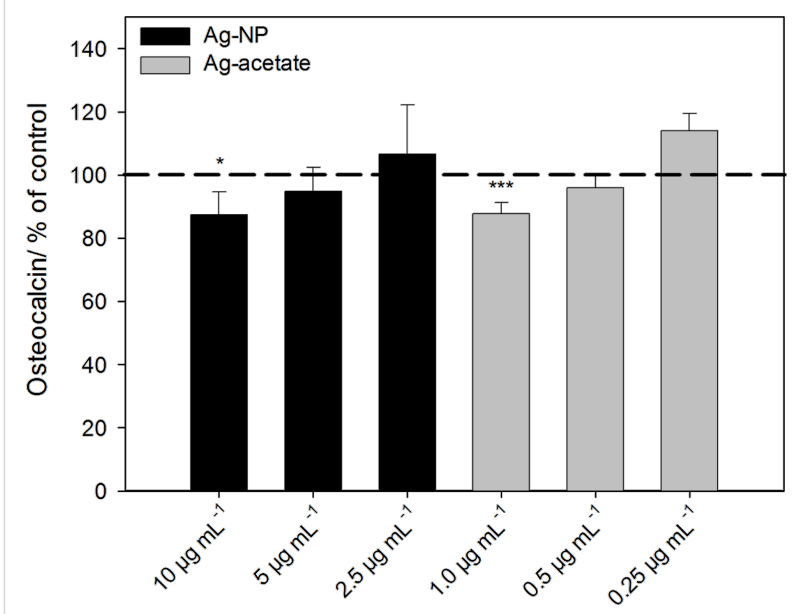

Figure 8: Release of the osteogenic differentiation marker osteocalcin after incubation of hMSCs with $\mathrm{Ag}-\mathrm{NP} / \mathrm{Ag}^{+}$ions. The data are expressed as the mean $\pm \mathrm{SD}$ ( $n=7$ independent experiments), given as the percent of the control (osteocalcin $15.6 \pm 6 \mathrm{ng} \cdot \mathrm{mL}^{-1}$; cells cultured without silver, dashed line). The asterisks $\left(^{*}\right)$ indicate significant differences with respect to the control $\left({ }^{*} p<0.05,{ }^{* * *} p<0.001\right)$.

In addition, the release of the chondrocyte biomarker aggrecan in the presence or absence of $\mathrm{Ag}-\mathrm{NP} / \mathrm{Ag}^{+}$ions was measured by using ELISA (Figure 10). The structural proteoglycan aggrecan is found in the extracellular matrix of cartilage and is a suitable biomarker for chondrogenic differentiation of MSCs at late time points (at least three weeks), as in our experimental setup [35] Aggrecan was not detectable in the supernatants of undifferentiated MSCs, but it was expressed in the supernatants of cells that were cultured in the presence of the chondrogenic-differentiation media. Similar to the alcian blue staining, there were no significant differences between cells that were treated with or without silver (ionic or particulate).

\section{Discussion}

In the present study, we analyzed the effects of $\mathrm{Ag}-\mathrm{NP}$ on hMSCs differentiation. We have shown that Ag-NP with a size of $80 \mathrm{~nm}$ do not enter the cell nucleus and that silver agglomerates appeared primarily within the endo-lysosomes after $24 \mathrm{~h}$. Fröhlich et al. [36] have reported that access to other organelles depends on the particle size.

Similarly, as suggested by Berry et al., the uptake of nanoparticles is constrained by the dimensions of the nuclear pore because gold nanoparticles (Au-NP) with a size of $5 \mathrm{~nm}$ appeared in the nuclei of a human fibroblast cell line, whereas particles larger than $30 \mathrm{~nm}$ were retained in the cytoplasm [37]. In the present study, we used silver nanoparticles with a size of $80 \mathrm{~nm}$, and thus, no silver agglomerates were found in the nucleus. Important aspects of the behavior of Ag-NP, such as cell toxicity or antimicrobial potency, are related to the reactivity of silver ions [38-41]. As we have shown previously, the rate and degree of the dissolution of Ag-NP depends on their surface functionalization, their concentration, the oxygen content and temperature [19,21]. Therefore, it has been suggested that Ag-NP act as a "Trojan horse" that enables the release of metal ions within cells [42-44]. In this context, it is important to analyze the influence of subtoxic concentrations of nano-silver
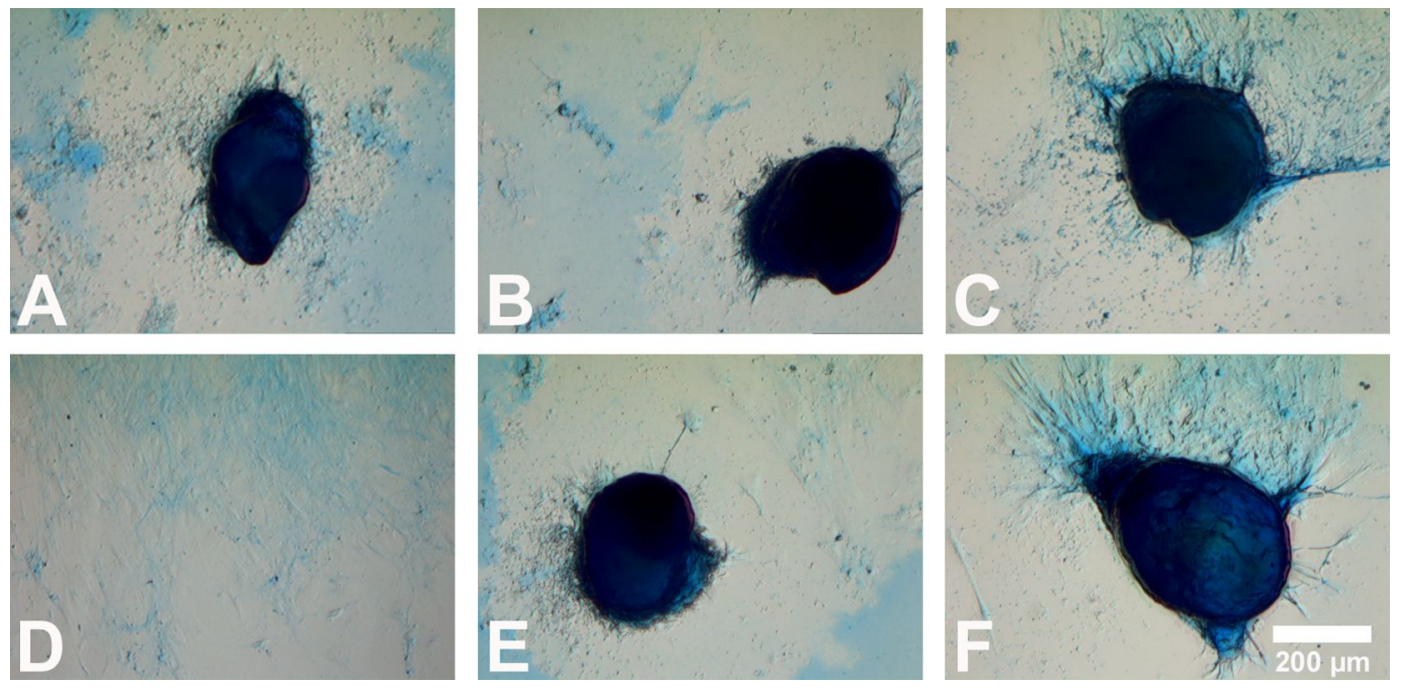

Figure 9: Influence of Ag-NP/Ag ${ }^{+}$ions on the chondrogenic differentiation of hMSCs. After $21 \mathrm{~d}$ of cell culture under chondrogenic conditions (brightfield images), alcian blue staining was used to visualize polyanionic glycosaminoglycan chains of proteoglycans in the cultured cells. hMSCs incubated in the presence of chondrogenic-differentiation media served as the positive control (A). hMSCs incubated in the presence of RPMI/FCS served as the negative control (D). Cells were incubated with $10 \mu \mathrm{g} \cdot \mathrm{mL}^{-1}(B)$ or with $5 \mu \mathrm{g} \cdot \mathrm{mL}^{-1}(C)$ Ag-NP in the presence of chondrogenic differentiation media. In addition, cells were incubated with $1.0 \mu \mathrm{g} \cdot \mathrm{mL}^{-1}(\mathrm{E})$ or $0.5 \mu \mathrm{g} \cdot \mathrm{mL}^{-1}(\mathrm{~F}) \mathrm{Ag}^{+}$ions in the presence of chondrogenic differentiation media. 


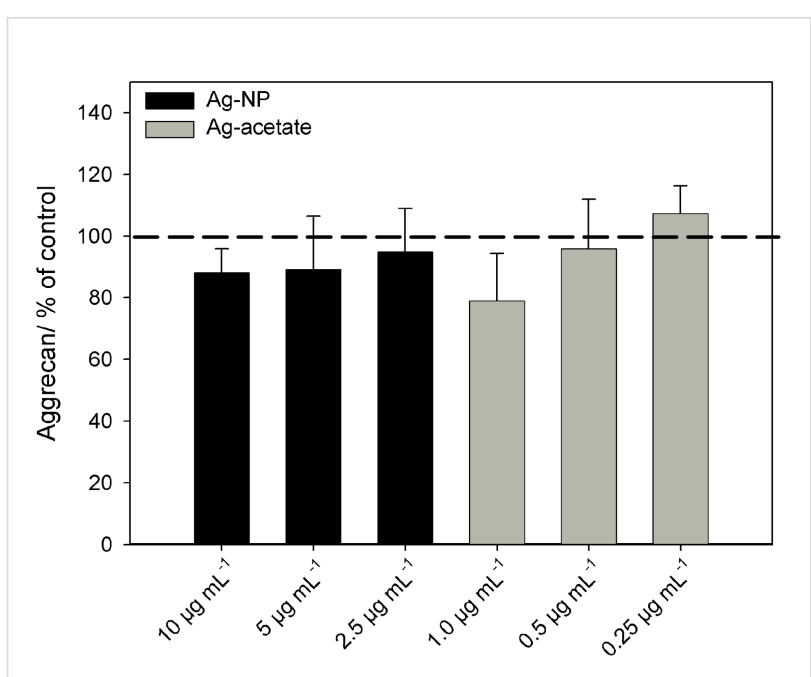

Figure 10: Release of the chondrogenic differentiation marker aggrecan after incubation of hMSCs with $\mathrm{Ag}-\mathrm{NP} / \mathrm{Ag}^{+}$ions. The data are expressed as the mean $\pm \mathrm{SD}$ ( $n=7$ independent experiments), given as the percentage of the control (aggrecan $5 \pm 1.9 \mathrm{ng} \cdot \mathrm{mL}^{-1}$; cells cultured without silver, dashed line).

on stem cell differentiation after long-term incubation. Human MSCs may come into close contact with nano-silver, e.g., after the implantation of an Ag-NP-coated implant [17,45]. To date, little is known about the influence of nanoparticles on stem cell differentiation. In this study, we have shown that the adipogenic and osteogenic differentiation of hMSCs was impaired at subtoxic concentrations of $\mathrm{Ag}-\mathrm{NP}$ and $\mathrm{Ag}^{+}$ions, whereas chondrogenic differentiation was not influenced by the presence of silver. Similar results were observed by Fan et al. when using gold nanoparticles [46]. These nanoparticles, with a size of $30 \mathrm{~nm}$, led to decreases in the osteogenic and adipogenic differentiation capability of human bone MSCs. In addition, Kohl et al. reported that Au-NP led to a decrease in mitochondrial activity and inhibited lipid formation that depend on the concentration of the applied particles [47]. Therefore, the expression of adipogenic-specific genes and proteins is also expected to be attenuated in MSCs upon nanoparticle treatment [48]. This was confirmed in our study by the decreased secretion of specific biomarkers, including adiponectin (adipocytes) and osteocalcin (osteoblasts).

Liu et al. also used PCR to analyze osteocalcin expression in hMSCs at an early time-point (day 10) after osteogenic induction in the presence of Ag-NP [49]. The authors found no differences with respect to control cells without Ag-NP exposure, although a decrease in cell viability was also observed at Ag-NP concentrations $\geq 10 \mu \mathrm{g} \cdot \mathrm{mL}^{-1}$. Pauksch et al. analyzed the expression of alkaline phosphatase in MSCs in the presence of Ag-NP (up to $1 \mu \mathrm{g} \cdot \mathrm{mL}^{-1}$ ) after prolonged cell sulture ( $35 \mathrm{~d}$ ). In contrast to the significant inhibition in cell proliferation observed at the highest concentration of Ag-NP, the authors found no influence on the activity of alkaline phosphatase [50].

Metal ions are generally assumed to have a significant effect on the activation of redox-sensitive transcription factors such as NF- $\kappa$ B or AP-1 [51]. These transcription factors are involved in inflammatory responses and are important for processes such as differentiation and cell growth [52]. Silver-mediated oxidative stress can lead to the nuclear translocation of NF- $\kappa B$, which regulates pro- and anti-inflammatory genes [53-55]. For example, we previously demonstrated that Ag-NP-induced an activation of hMSCs and monocytes that was characterized by differential cytokine release (e.g., increased IL-8 or decreased IL-6 release), the increased expression of adhesion molecules such as CD54 and the enhanced generation of reactive oxygen species (ROS) [9,10]. As such, these observations indicated that the generation of ROS can be regarded as a common mechanism for silver-induced effects.

Other reports also showed that mechanical stress can inhibit adipogenesis, which is associated with the down-regulation of related marker genes $[48,56,57]$. However, whether the response is triggered by mechanical stress during membrane interaction and uptake or by the interaction of particles with intracellular signaling structures is still not clear. Studies specifically investigating the effect of silver on stem cell differentiation are rare $[49,50,58]$. Albers et al. have shown that Ag-NP with a size of $50 \mathrm{~nm}$ also led to a concentration-dependent decrease in murine osteogenic cell differentiation [59]. However, Samberg et al. reported no influence of Ag-NP (commercially available $10 \mathrm{~nm}$ and $20 \mathrm{~nm}$ particles) on adipose-derived stem cells based on photographic image analyses [60]. In contrast, we used bone-marrow-derived stem cells and additionally performed chondrogenic differentiation and quantitative analyses of histochemical staining, which might explain the differences in the obtained results. In the case of the chondrogenic differentiation, a quantitative analysis of alcian blue staining was not possible due to the 3-dimensional growth of chondrogenic-derived hMSCs. However, cell morphology and aggrecan release demonstrated no differences compared with cells cultured without silver. Similar results were obtained by Tautzenberger et al., who demonstrated that the chondrogenic differentiation of hMSCs was not influenced in the presence of polystyrene nanoparticles [31].

A major difficulty when comparing studies on the biological effects of nano-silver is the difference in the nature of the respective particle. In addition to the size, shape, or surface charge, the surface coating or functionalization used to stabilize the monodisperse nature is of critical importance. An important requirement is the agglomeration control because the agglomer- 
ation of particles might already occur within the incubation media [18,21]. Agglomerated nano-silver will follow different uptake mechanisms, if at all, and biological responses might occur at much higher total silver concentrations compared with monodispersed silver nanoparticles. In summary, Ag-NP exert multiple effects on cellular physiology and signal transduction, which can lead to alterations in gene expression. The adipogenic and osteogenic differentiation of hMSCs is clearly down-regulated even at subtoxic concentrations of Ag-NP.

\section{Conclusion}

In conclusion, silver nanoparticles with a size of $80 \mathrm{~nm}$ (hydrodynamic diameter) were ingested into hMSCs as nanoparticulate material. After cellular uptake, these Ag-NP were mainly associated with the endo-lysosomal cell compartment and occurred as silver agglomerates within these organelles. Exposure of hMSCs to subtoxic concentrations of Ag-NP, as well as to $\mathrm{Ag}^{+}$ions, during differentiation into adipogenic or osteogenic lineage resulted in a significant concentration-dependent decrease in differentiation capacity. Furthermore, the chondrogenic differentiation of hMSCs was not influenced by the presence of silver under these experimental conditions. In summary, the internalization of nano-silver into stem cells had a significant influence on diverse aspects of cellular functions. Therefore, more studies are needed to investigate the effects of nanosilver in directing stem cell behavior in order to predict the possible health risks.

\section{Experimental \\ Synthesis of silver nanoparticles}

Polyvinylpyrrolidone (PVP)-coated silver nanoparticles were synthesized by reduction with glucose in the presence of PVP as described previously [19,21]. The final silver concentration in all dispersions was determined by atomic absorption spectroscopy (AAS, Thermo Electron Corporation, M-Series). The hydrodynamic diameter and the zeta-potential of the dispersed particles were measured by dynamic light scattering (DLS) using a Malvern Zetasizer Nano ZS. The z-average value was used as the average particle diameter. The polydispersity index (PDI) was below 0.3 in all cases, indicating the absence of aggregates. Scanning electron microscopy (FEI Quanta 400 ESEM instrument) revealed a spherical shape of the Ag-NP used with a metallic core of $50 \pm 20 \mathrm{~nm}$. The hydrodynamic diameter of the nanoparticles was $80 \mathrm{~nm}$ as measured by DLS. Note that the hydrodynamic diameter includes the polymer layer and the hydration shell and is therefore always larger than the pure metal diameter of the silver core as determined by electron microscopy under high vacuum.

PVP (K30, Povidon 30; Fluka, molecular weight $40,000 \mathrm{~g} \cdot \mathrm{mol}^{-1}$ ), trisodium citrate dihydrate (Fluka, p.a.), silver nitrate (Fluka, p.a.), and D-(+)-glucose (Baker) were used. Ultrapure water was prepared with an ELGA Purelab ultra instrument. Ag-NP were stored under argon to prevent partial oxidative dissolution (which drastically influences nanoparticle toxicity) prior to cell culture experiments $[19,21]$.

\section{Cell culture}

Human mesenchymal stem cells (hMSCs, 3rd to 7th passage, Lonza, Walkersville Inc., MD, USA) were cultured in RPMI1640 cell culture medium (Life Technologies, Darmstadt, Germany) containing $10 \%$ fetal calf serum (FCS, Life Technologies $)$ and L-glutamine $\left(0.3 \mathrm{~g} \cdot \mathrm{L}^{-1}\right.$, Life Technologies $)$ while using $75 \mathrm{~cm}^{2}$ flasks (Falcon, Becton Dickinson $\mathrm{GmbH}$, Heidelberg, Germany). Cells were maintained at $37{ }^{\circ} \mathrm{C}$ in a humidified $5 \% \mathrm{CO}_{2}$ atmosphere. hMSCs were sub-cultivated every 7-14 d depending on cell proliferation. Adherent cells were washed with phosphate buffered saline solution (PBS, Life Technologies) and detached from the culture flasks by the addition of $0.2 \mathrm{~mL} \cdot \mathrm{cm}^{-2} 0.25 \%$ trypsin $/ 0.05 \%$ ethylenediaminetetraacetic acid (EDTA, Sigma-Aldrich, Taufkirchen, Germany) for $5 \mathrm{~min}$ at $37^{\circ} \mathrm{C}$. Subsequently, the hMSCs were collected and washed twice with RPMI1640/10\% FCS.

\section{Determination of cellular Ag-NP uptake by laser scanning microscopy (LSM)}

LSM was performed to demonstrate the occurrence of intracellular silver nanoparticles in hMSCs after incubation. Therefore, hMSCs were subconfluently grown on 2-well Lab$\mathrm{Tek}^{\mathrm{TM}}$ glass chamber slides (Thermo Fisher Scientific, Langenselbold, Germany) and subsequently washed and exposed to $20 \mu \mathrm{g} \cdot \mathrm{mL}^{-1} \mathrm{Ag}$-NP for $24 \mathrm{~h}$ under cell culture conditions. Microscopic uptake studies require preferably high (but still non-toxic after $24 \mathrm{~h}$ ) concentrations of Ag-NP to obtain an optimal read-out. After incubation, hMSCs were labeled with specific cell organelle fluorescent probes (Life Technologies). As a marker for late endosomes and lysosomes, the cells were incubated with $50 \mathrm{nM}$ LysoTracker Red DND 99 in pure RPMI1640 for $30 \mathrm{~min}$ at $37^{\circ} \mathrm{C}$. To label the nucleus, the cells were incubated with $162 \mu \mathrm{M}$ Hoechst 33342 in pure RPMI 1640 for $5 \mathrm{~min}$ at $37^{\circ} \mathrm{C}$. After three rinses in RPMI1640, the cells were mounted on glass chamber slides. Images were taken with a laser scanning microscope (LSM 700; Zeiss) equipped with a $40 \times$ oil-immersion objective using Zeiss 2010 software.

\section{Induction of hMSCs differentiation}

For adipogenic and osteogenic differentiation, hMSCs were seeded subconfluently into 24-well tissue culture plates (Falcon, Becton Dickinson GmbH, Heidelberg, Germany) and cultured in RPMI $/ 10 \% \mathrm{FCS}$ at $37{ }^{\circ} \mathrm{C}$ under cell culture conditions. Non- 
adherent cells were aspirated with the medium after $24 \mathrm{~h}$ of cultivation, and cells were cultured for $24 \mathrm{~h}$ in the presence or absence of different concentrations of freshly prepared Ag-NP or $\mathrm{Ag}^{+}$ions (silver acetate solution, normalized to the silver content) in a humidified atmosphere of $5 \% \mathrm{CO}_{2}$.

PVP-coated spherical Ag-NP were dispersed in sterile ultrapure water at $1 \mathrm{mg} \cdot \mathrm{mL}^{-1}$ as the stock solution. Dilutions of Ag-NP were also prepared in ultrapure water. The final Ag-NP concentrations were $10 \mu \mathrm{g} \cdot \mathrm{mL}^{-1}, 5 \mu \mathrm{g} \cdot \mathrm{mL}^{-1}$ and $2.5 \mu \mathrm{g} \cdot \mathrm{mL}^{-1}$, and the final silver ion concentrations were $1.0 \mu \mathrm{g} \cdot \mathrm{mL}^{-1}, 0.5 \mu \mathrm{g} \cdot \mathrm{mL}^{-1}$ and $0.25 \mu \mathrm{g} \cdot \mathrm{mL}^{-1}$. All of the silver concentrations given here refer to the amount of silver as determined by AAS.

After $24 \mathrm{~h}$ of incubation, the particle-containing medium was removed, and the cells were washed and incubated with adipogenic or osteogenic differentiation medium (Life Technologies). After $14 \mathrm{~d}$ (adipogenesis) or $21 \mathrm{~d}$ (osteogenesis) of cultivation, adipogenic cultures were processed for oil red staining or Bodipy ${ }^{493 / 503}$ staining and osteogenic cultures were processed for alizarin red staining. To guarantee non-toxic effects during these prolonged incubation periods, lower Ag-NP-concentrations were used compared with the uptake studies (up to $10 \mu \mathrm{g} \cdot \mathrm{mL}^{-1}$ ).

To support chondrogenic differentiation, 400,000 cells were incubated with different concentrations of $\mathrm{Ag}-\mathrm{NP} / \mathrm{Ag}^{+}$ions for $24 \mathrm{~h}$ and pelleted afterwards. After cultivation for $3 \mathrm{~h}$ under cell culture conditions, prewarmed chondrogenic differentiation medium was added. After $21 \mathrm{~d}$ of cultivation, chondrogenic pellets were stained by alcian blue. Undifferentiated hMSCs incubated in the presence of RPMI/10\% FCS served as the negative control. hMSCs incubated in the presence of the corresponding differentiation medium alone served as the positive control.

In all experiments, hMSCs treated with adipogenic, osteogenic or chondrogenic differentiation medium in the presence of nanoparticles were compared with cells cultured without differentiation medium in the presence of RPMI/10\% FCS and $\mathrm{Ag}-\mathrm{NP} / \mathrm{Ag}^{+}$ions and with cells incubated without $\mathrm{Ag}-\mathrm{NPs} / \mathrm{Ag}^{+}$ ions in the presence of the differentiation medium alone $(100 \%$ differentiation).

\section{Measurement of cell viability}

The viability of the incubated hMSCs was analyzed by using calcein-acetoxymethylester (calcein-AM, Calbiochem, Schwalbach, Germany) fluorescence staining. After incubation for $24 \mathrm{~h}$, the nanoparticle- and silver ion-treated cells were washed, and particle-free medium (RPMI/10\% FCS or adipogenic, osteogenic differentiation medium) was added. After $14 \mathrm{~d}$ or $21 \mathrm{~d}$, the cells were washed twice with RPMI and incubated with Calcein-AM $(1 \mu \mathrm{M})$ at $37^{\circ} \mathrm{C}$ for 30 min under cell culture conditions. Subsequently, the adherent cells were washed again with RPMI and analyzed by fluorescence microscopy (Olympus MVX10, Olympus, Hamburg, Germany). Fluorescence micrographs were taken (Cell P, Olympus) and digitally processed using Adobe Photoshop ${ }^{\circledR}$ 7.0.

\section{Quantitative cell differentiation}

Staining with alizarin red S was used to monitor the degree of mineralization of osteogenic differentiated hMSCs in the presence or absence of Ag-NP/silver ions. Briefly, cells were washed with PBS and fixed with $10 \%$ formaldehyde for $30 \mathrm{~min}$. After fixation, the cells were washed three times with distilled water and stained with $1 \%$ alizarin red S solution (SigmaAldrich) for $5 \mathrm{~min}$. The differentiation rates of hMSCs were assessed on an EVOS xl core light microscope (PEQLAB Biotechnologie GMBH, Erlangen, Germany). To quantify the staining, the cells were washed with distilled water and incubated with $1 \mathrm{~mL}$ of $10 \%$ cetylpyridinium chloride (SigmaAldrich) with shaking on a plate rotator. The extracted supernatant was collected, and the optical density was measured at a wavelength of $570 \mathrm{~nm}$ by using a Microplate Reader (MRX Revelation, Dynex Technologies). The mineralization rate was expressed as the percentage of cells cultured under osteogenic conditions in the absence of silver.

The adipogenic differentiation rates of hMSCs in the absence or presence of $\mathrm{Ag}-\mathrm{NP} / \mathrm{Ag}^{+}$ions was determined by staining intracytoplasmic lipids and lipoproteins in the vacuoles of cells using oil red O (Sigma-Aldrich) or Bodipy ${ }^{493 / 503}$. Briefly, after $14 \mathrm{~d}$ of incubation, the cells were washed twice with PBS, fixed with $10 \%$ formaldehyde for $10 \mathrm{~min}$ and then stained with oil red O solution or Bodipy ${ }^{493 / 503}$ for 15 min. Subsequently, cells were washed twice with distilled water, and the adipogenic differentiation rates of hMSCs were assessed with an EVOS xl core light microscope (PEQLAB Biotechnologie GMBH, Erlangen, Germany) or by fluorescence microscopy (Olympus BX63, Olympus, Hamburg, Germany). To quantify the oil red O content, hMSCs were washed three times with DPBS to remove background staining, and 4\% Nonidet P-40 (Roche, Mannheim, Germany) was added to resolve oil red O. The quantitative analysis of lipid accumulation of oil red $\mathrm{O}$ was performed by using a UV-vis spectrophotometer (Ultraspec 3100 pro, Amersham Bioscience, GE Healthcare, Freiburg Germany) at a wavelength of $520 \mathrm{~nm}$ to measure the optical density of the extracted oil droplets. For Bodipy ${ }^{493 / 503}$ fluorescence quantification microphotographs were taken (Olympus CellP, Olympus, Hamburg, Germany) and digitally processed using Adobe Photoshop ${ }^{\circledR}$ 7.0. 
Chondrogenic differentiation was analyzed by staining the pellet cultures with alcian blue 8GX (Sigma-Aldrich). After $21 \mathrm{~d}$ of incubation, cells were washed twice with DPBS and fixed with $4 \%$ formaldehyde solution for $30 \mathrm{~min}$. After fixation, cells were washed with DPBS and stained with $1 \%$ alcian blue solution for a further $30 \mathrm{~min}$. Subsequently, pellet cultures were rinsed three times with $0.1 \mathrm{~N} \mathrm{HCL}$ and additionally with water to neutralize the acidity. Incubation with alcian blue stains the polyanionic glycosaminoglycan chains of proteoglycans in chondrocytes. The chondrogenic differentiation of hMSCs was assessed on an EVOS xl core light microscope (PEQLAB Biotechnologie GMBH).

\section{ELISA}

The secretion of specific differentiation biomarkers (adiponectin, osteocalcin and aggrecan) by $\mathrm{Ag}-\mathrm{NP} / \mathrm{Ag}^{+}$iontreated hMSCs was quantified in the media by using specific enzyme-linked immunosorbent assays (ELISA). The antibodies and the recombinant human protein standards were supplied by R\&D Systems (Adiponectin; Wiesbaden, Germany), Life Technologies (Aggrecan; Darmstadt, Germany) and Quidel (Osteocalcin; Berlin, Germany). The biomarkers were quantified using the manufacturer's ELISA protocols. The ELISA microtiter plates were evaluated on an ELISA reader (MRX Revelation, Dynex Technologies) set to $450 \mathrm{~nm}$.

\section{Statistical analysis}

Data are expressed as the mean \pm SD of at least three independent experiments. Analysis of the data distribution was performed using the Student's $t$-test to analyze the significance of differences between the treated group and the control group without silver exposure. Significant differences between groups of data were assessed by performing One Way ANOVA followed by the Tukey post-hoc test. Values of $p$ of less than 0.05 were considered statistically significant.

\section{Acknowledgements}

We thank the Deutsche Forschungsgemeinschaft (DFG) for financial support within the Priority Program NanoBioResponses (SPP1313) and within the Nachwuchsakademie Medizintechnik (NAMT).

\section{References}

1. Wijnhoven, S. W. P.; Peijnenburg, W. J. G. M.; Herberts, C. A.; Hagens, W. I.; Oomen, A. G.; Heugens, E. H. W.; Roszek, B.; Bisschops, J.; Gosens, I.; Van De Meent, D.; Dekkers, S.; De Jong, W. H.; van Zijverden, M.; Sips, A. J. A. M.; Geertsma, R. E. Nanotoxicology 2009, 3, 109-138. doi:10.1080/17435390902725914

2. Brett, D. W. Ostomy Wound Manage. 2006, 52, 34-41.

3. Laban, G.; Nies, L. F.; Turco, R. F.; Bickham, J. W.; Sepúlveda, M. S. Ecotoxicology 2010, 19, 185-195. doi:10.1007/s10646-009-0404-4
4. Matsumura, Y.; Yoshikata, K.; Kunisaki, S.-i.; Tsuchido, T. Appl. Environ. Microbiol. 2003, 69, 4278-4281. doi:10.1128/AEM.69.7.4278-4281.2003

5. Roe, D.; Karandikar, B.; Bonn-Savage, N.; Gibbins, B.; Roullet, J.-B. J. Antimicrob. Chemother. 2008, 61, 869-876. doi:10.1093/jac/dkn034

6. Gupta, A.; Matsui, K.; Lo, J.-F.; Silver, S. Nat. Med. 1999, 5, 183-188. doi:10.1038/5545

7. Morones, J. R.; Elechiguerra, J. L.; Camacho, A.; Holt, K.; Kouri, J. B.; Ramírez, J. T.; Yacaman, M. J. Nanotechnology 2005, 13, 2346-2353. doi:10.1088/0957-4484/16/10/059

8. Singh, R.; Singh, D. J. Mater. Sci.: Mater. Med. 2012, 23, 2649-2658. doi:10.1007/s10856-012-4730-3

9. Greulich, C.; Diendorf, J.; Geßmann, J.; Simon, T.; Habijan, T.; Eggeler, G.; Schildhauer, T. A.; Epple, M.; Köller, M. Acta Biomater. 2011, 9, 3505-3514. doi:10.1016/j.actbio.2011.05.030

10. Greulich, C.; Kittler, S.; Epple, M.; Muhr, G.; Köller, M. Langenbecks Arch. Surg. 2009, 394, 495-502. doi:10.1007/s00423-009-0472-1

11. Greulich, C.; Diendorf, J.; Simon, T.; Eggeler, G.; Epple, M.; Köller, M. Acta Biomater. 2011, 7, 347-354. doi:10.1016/j.actbio.2010.08.003

12. Chernousova, S.; Epple, M. Angew. Chem., Int. Ed. 2012, 52, 1636-1653. doi:10.1002/anie.201205923

13. Choi, O.; Deng, K. K.; Kim, N.-J.; Ross, L.; Surampalli, R. Y.; Hu, Z. Water Res. 2008, 42, 3066-3074. doi:10.1016/j.watres.2008.02.021

14. AiHui, L.; NanNan, Z.; ZhiLiang, J.; RongJin, L. Sci. China, Ser. B: Chem. 2008, 51, 226-232.

15. Liochev, S. Met. lons Biol. Syst. 1999, 36, 1-39.

16. Jones, A. M.; Garg, S.; He, D.; Pham, A. N.; Waite, T. D. Environ. Sci. Technol. 2011, 45, 1428-1434. doi:10.1021/es103757c

17. Greulich, C.; Braun, D.; Peetsch, A.; Diendorf, J.; Siebers, B.; Epple, M.; Köller, M. RSC Adv. 2012, 2, 6981-6987. doi:10.1039/c2ra20684f

18. Kittler, S.; Greulich, C.; Gebauer, J. S.; Diendorf, J.; Treuel, L.; Ruiz, L.; Gonzalez-Calbet, J. M.; Vallet-Regi, M.; Zellner, R.; Köller, M.; Eplle, M. J. Mater. Chem. 2009, 20, 512-518. doi:10.1039/b914875b

19. Kittler, S.; Greulich, C.; Diendorf, J.; Köller, M.; Epple, M. Chem. Mater. 2010, 22, 4548-4554. doi:10.1021/cm100023p

20. Lok, C.-N.; Ho, C.-M.; Chen, R.; He, Q.-Y.; Yu, W.-Y.; Sun, H.; Tam, P. K.-H.; Chiu, J.-F.; Che, C.-M. JBIC, J. Biol. Inorg. Chem. 2007, 12, 527-534. doi:10.1007/s00775-007-0208-z

21. Loza, K.; Diendorf, J.; Greulich, C.; Ruiz-Gonzales, L.; Gonzalez-Calbet, J. M.; Vallet-Regi, M.; Köller, M.; Epple, M. J. Mater. Chem. B 2014, 2, 1634-1643. doi:10.1039/C3TB21569E

22. Liu, J.; Hurt, R. H. Environ. Sci. Technol. 2010, 44, 2169-2175. doi:10.1021/es9035557

23. Choi, O.; Clevenger, T. E.; Deng, B.; Surampalli, R. Y.; Ross, L.; Hu, Z. Water Res. 2009, 43, 1879-1886. doi:10.1016/j.watres.2009.01.029

24. Sosa, Y. D.; Rabelero, M.; Treviño, M. E.; Saade, H.; López, R. G. J. Nanomater. 2010, 392572. doi:10.1155/2010/392572

25. Pittenger, M. F.; Mackay, A. M.; Beck, S. C.; Jaiswal, R. K.; Douglas, R.; Mosca, J. D.; Moorman, M. A.; Simonetti, D. W.; Craig, S.; Marshak, D. R. Science 1999, 284, 143-147. doi:10.1126/science.284.5411.143

26. Baksh, D.; Song, L.; Tuan, R. S. J. Cell. Mol. Med. 2004, 8, 301-316. doi:10.1111/j.1582-4934.2004.tb00320.x

27. Ahamed, M.; Karns, M.; Goodson, M.; Rowe, J.; Hussain, S.; Schlager, J.; Hong, Y. Toxicol. Appl. Pharmacol. 2008, 233, 404-410. doi:10.1016/j.taap.2008.09.015 
28. Feng, Q. L.; Wu, J.; Chen, G. Q.; Cui, F. Z.; Kim, T. N.; Kim, J. O. J. Biomed. Mater. Res. 2000, 52, 662-668. doi:10.1002/1097-4636(20001215)52:4<662::AID-JBM10>3.0.CO;2-3

29. Ruparelia, J. P.; Chatterjee, A. K.; Duttagupta, S. P.; Mukherji, S. Acta Biomater. 2008, 4, 707-716. doi:10.1016/j.actbio.2007.11.006

30. Slawson, R. M.; Lee, H.; Trevors, J. T. Biol. Met. 1990, 3, 151-154. doi:10.1007/BF01140573

31. Tautzenberger, A.; Lorenz, S.; Kreja, L.; Zeller, A.; Musyanovych, A.; Schrezenmeier, H.; Landfester, K.; Mailänder, V.; Ignatius, A. Biomaterials 2010, 31, 2064-2071. doi:10.1016/j.biomaterials.2009.11.099

32. Hsiao, J.-K.; Tsai, C.-P.; Chung, T.-H.; Hung, Y.; Yao, M.; Liu, H.-M.; Mou, C.-Y.; Yang, C.-S.; Chen, Y.-C.; Huang, D.-M. Small 2008, 4, 1445-1452. doi:10.1002/smll.200701316

33. Shah, B. S.; Clark, P. A.; Moioli, E. K.; Stroscio, M. A.; Mao, J. J. Nano Lett. 2007, 7, 3071-3079. doi:10.1021/nl071547f

34. Qi, H.; Aguiar, D. J.; Williams, S. M.; La Pean, A.; Pan, W.; Verfaillie, C. M. Proc. Natl. Acad. Sci. U. S. A. 2003, 100, 3305-3310. doi:10.1073/pnas.0532693100

35. Boeuf, S.; Graf, F.; Fischer, J.; Moradi, B.; Little, C. B.; Richter, W. Eur. Cells Mater. 2012, 23, 320-332.

36. Fröhlich, E.; Samberger, C.; Kueznik, T.; Absenger, M.; Roblegg, E.; Zimmer, A.; Pieber, T. R. J. Toxicol. Sci. 2009, 34, 363-375. doi:10.2131/jts.34.363

37. Berry, C. C.; de la Fuente, J. M.; Mullin, M.; Chu, S. W. L.; Curtis, A. S. G. IEEE Trans. NanoBiosci. 2007, 6, 262-269. doi:10.1109/TNB.2007.908973

38. Foldbjerg, R.; Dang, D. A.; Autrup, H. Arch. Toxicol. 2010, 85, 743-750. doi:10.1007/s00204-010-0545-5

39. Juan, L.; Zhimin, Z.; Anchun, M.; Lei, L.; Jingchao, Z. J. Nanomedicine 2010, 5, 261-267. doi:10.2147/IJN.S8810

40. Kawata, K.; Osawa, M.; Okabe, S. Environ. Sci. Technol. 2009, 43, 6046-6051. doi:10.1021/es900754q

41. Li, P.-W.; Kuo, T.-H.; Chang, J.-H.; Yeh, J.-M.; Chan, W.-H. Toxicol. Lett. 2010, 197, 82-87. doi:10.1016/j.toxlet.2010.05.003

42. Park, E.-J.; Yi, J.; Kim, Y.; Choi, K.; Park, K. Toxicol. in Vitro 2010, 24, 872-878. doi:10.1016/j.tiv.2009.12.001

43. Quadros, M. E.; Marr, L. C. J. Air Waste Manage. Assoc. 2010, 60, 770-781. doi:10.3155/1047-3289.60.7.770

44. Limbach, L. K.; Wick, P.; Manser, P.; Grass, R. N.; Bruinink, A.; Stark, W. J. Environ. Sci. Technol. 2007, 41, 4158-4163. doi:10.1021/es062629t

45. El-Sadik, A. O.; El-Ansary, A.; Sabry, S. M. Clin. Pharmacol.: Adv. Appl. 2010, 2, 9-16. doi:10.2147/CPAA.S8931

46. Fan, J. H.; Hung, W. I.; Li, W. T.; Yeh, J. M. IFMBE Proc. 2009, 23 , 870-873. doi:10.1007/978-3-540-92841-6_214

47. Kohl, Y.; Gorgup, E.; Katsen-Globa, A.; Büchel, C.; von Briesen, H.; Thielecke, H. J. Nanopart. Res. 2011, 13, 6789-6803. doi:10.1007/s11051-011-0587-5

48. Yi, C.; Liu, D.; Fong, C. C.; Zhang, J.; Yang, M. ACS Nano 2010, 4, 6439-6448. doi:10.1021/nn101373r

49. Liu, X.; He, W.; Fang, Z.; Kienzle, A.; Feng, Q. J. Biomed. Nanotechnol. 2014, 10, 1277-1285. doi:10.1166/jbn.2014.1824

50. Pauksch, L.; Hartmann, S.; Rohnke, M.; Szalay, G.; Alt, V.; Schnettler, R.; Lips, K. S. Acta Biomater. 2014, 10, 439-449. doi:10.1016/j.actbio.2013.09.037

51. Valko, M.; Rhodes, C. J.; Moncol, J.; Izakovic, M.; Mazur, M. Chem.-Biol. Interact. 2006, 160, 1-40. doi:10.1016/j.cbi.2005.12.009
52. Ghosh, S.; Hayden, M. S. Nat. Rev. Immunol. 2008, 8, 837-848. doi:10.1038/nri2423

53. Loitsch, S. M.; von Mallinckrodt, C.; Kippenberger, S.; Steinhilber, D.; Wagner, T. O.; Bargon, J. Biochem. Biophys. Res. Commun. 2000, 276, 571-578. doi:10.1006/bbrc.2000.3504

54. Yoshimaru, T.; Suzuki, Y.; Inoue, T.; Niide, O.; Ra, C. Free Radical Biol. Med. 2006, 40, 1949-1959. doi:10.1016/j.freeradbiomed.2006.01.023

55. Johnston, H. J.; Semmler-Behnke, M.; Brown, D. M.; Kreyling, W.; Tran, L.; Stone, V. Toxicol. Appl. Pharmacol. 2010, 242, 66-78. doi:10.1016/j.taap.2009.09.015

56. Rubin, C. T.; Capilla, E.; Luu, Y. K.; Busa, B.; Crawford, H.; Nolan, D. J.; Mittal, V.; Rosen, C. J.; Pessin, J. E.; Judex, S. Proc. Natl. Acad. Sci. U. S. A. 2007, 104, 17879-17884. doi:10.1073/pnas.0708467104

57. Sen, B.; Styner, M.; Xie, Z. H.; Case, N.; Rubin, C. T.; Rubin, J. J. Biol. Chem. 2009, 284, 34607-34617. doi:10.1074/jbc.M109.039453

58. Lim, P. N.; Shi, Z.; Neoh, K. G.; Ho, B.; Tay, B. Y.; Thian, E. S. Biomed. Mater. 2014, 9.

59. Albers, C. E.; Hofstetter, W.; Siebenrock, K. A.; Landmann, R.; Klenke, F. M. Nanotoxicology 2011, 7, 30-36. doi:10.3109/17435390.2011.626538

60. Samberg, M. E.; Loboa, E. G.; Oldenburg, S. J.; Monteiro-Riviere, N. A. Nanomedicine (London, U. K.) 2012, 7, 1197-1209. doi: $10.2217 / \mathrm{nnm} .12 .18$

\section{License and Terms}

This is an Open Access article under the terms of the Creative Commons Attribution License (http://creativecommons.org/licenses/by/2.0), which permits unrestricted use, distribution, and reproduction in any medium, provided the original work is properly cited.

The license is subject to the Beilstein Journal of Nanotechnology terms and conditions: (http://www.beilstein-journals.org/bjnano)

The definitive version of this article is the electronic one which can be found at: $\underline{\text { doi:10.3762/bjnano.5.214 }}$ 